\title{
A METAREFERENTIAL TURN AND MEDIATIZATION OF REALITY
}

\begin{abstract}
The qualitative leap in self-reflection of contemporary culture, which questions the permeability of the boundaries between reality and fictional worlds, accelerated by the development of digital art media in the 21st century, is labeled in theory as a 'metareferential turn'. It is primarily a shift away from hetero-referential focus on attempts to present objective reality and from its understanding towards self-realization that is possible only by looking at the whole: the non-human world as well as human artifacts, including media that portray and create a new, mediatized reality. Metareferences as a transmedial concept cognitively link narratives of different types of 'realities' by activating the process of metaization - moving from a referential or communicative level of consciousness to a higher, self-reflexive one. That makes the audience mentally participate in the creation of the metaleptogenic universe.
\end{abstract}

Keywords: metareferences, metaization, transmediality, metareferential turn, mediatization

\section{Introduction:}

Metareferences have occurred in speech and language since the very beginning of the development of culture and civilization, but the term itself is more recent. The development of media enabled the expansion of metareferences from written text into various forms of communication - auditory, visual, binary or quantum. Research in the field of literature has expanded to all other arts and media, thus enabling comparative analysis of phenomena and transmedial insights. This opens up a broad perspective of networking and connecting different artistic disciplines and media forms, enriching information, both semantically and aesthetically.

Defining metareferences is more difficult than noticing them in communication: "For the moment, metareferentiality can be said to denote all kinds of references to, or comments on, aspects of a medial artifact, and medium or media in general that issue from a logically higher 'meta-level' within a given artefact and elicits corresponding to self-referential reflections in the recipient"' (Wolf, 2009: v).

When it comes to media, it is desirable to overcome the distinction between artistic media forms - books, paintings, music, architecture and mass-media genres, since the contemporary age of internet communication seeks unification in creating and marketing messages to users across all available channels and platforms. Marshall McLuhan had a visionary perception of a future in which the media, rather than the

\footnotetext{
${ }^{1}$ Received August 2019 / Accepted November 2019

${ }^{2}$ E-mail: velibor.petkovic@filfak.ni.ac.rs
} 
means of production, would determine social relations, which is a metareference to Marx's "fallacy" that "the social being determines the social consciousness" (Marx, 1859; 1969). In this sense, all human extensions should be considered the media: "After three thousand years of explosion, by means of fragmentary and mechanical technologies, the Western world is imploding. During the mechanical ages we had extended our bodies in space. Today, after more than a century of electric technology, we have extended our central nervous system itself in a global embrace, abolishing both space and time as far as our planet is concerned." (McLuhan, 1971: 37).

McLuhan's thesis, "the medium itself is the message", must be balanced by paying attention to both the content of the text and the narratives whose metareferential linguistic potentials cognitively connect people more strongly than the internet.

Dan Sperber attributes to humans a "metarepresentational capacity" that is "no less fundamental than the faculty for language", and he claims that " $[u]$ nderstanding the character and the role of this [...] capacity might change our view of what it is to be human" (2000a: 6f.). Research requires a multidisciplinary approach to this human capacity to spot and find connections between concepts, which enables better understanding, "reading between the lines" and broader perception of available information. Transmedial studies of meta-phenomena can contribute to a more complete understanding of human meta-consciousness and to its orientation towards the development of media literacy and media education, as well as critical approach to artistic and informative content that will reduce the power of manipulating public opinion from different centers of ideological and financial power: „The key-term proposed here is 'metareference', which is used as a heuristically motivated umbrella term for all meta-phenomena occurring in the media" (Wolf, 2009: 12).

In addition to metareferences, a significant term that describes the process of their action is "metaization. "The term 'metaization' ('Metaisierung') was coined by Klaus W. Hempfer (1982: 130) who concentrates on metafiction and utterances, and above all means and media used for such utterances, self-reflexively becoming objects of reflection and communication in their own right - is a common feature not only of human thought and of language as a primary medium but also of literature as a secondary medium (using language) and arguably all other media as well" (Wolf 2009: 3).

The research of metaphenomena in literature as "narratorial selfconsciousness" (a term introduced by Wayne Booth in 1952) is increasingly being extended to the mass-media which are carriers of popular culture, encompassing "the full range of representations of identity, domination and resistance that form the very essence of media culture." (Kellner, 1995; 2004: 94). It is crucial to move from the study of metafiction to facticity, facts that are metareferentially related and don't allow the information blizzard to overwhelm an individual, but to make him understand better and gain deeper insights into important issues.

Linking different fields of artistic and media expression should overcome the monomedial research that has led to the creation of its own terminology, which has contributed to confinement in narrow frames without seeing the bigger picture. 
Contemporary narratology insists on that, proposing metareferences, metaization and mediatization (metaization in the media) for common terms that perfectly represent transmedial phenomena. There is a metareferential potential everywhere, and it is noted that in the contemporary culture, which is complementary to the postmodern, metareferences are of particular importance.

The most famous metareferential break throughs were recorded on film: Woody Allen first broke the "fourth wall" by metalepsis in "The Purple Rose of Cairo" (1985), and then the tandem Andrew Nicoll / Peter Weir recorded "The Truman Show" (1998), which places the entire reality in a television studio and leads the viewer to wonder if his existence has also turned into a spectacle whose scenario eludes him because it is written by someone unknown, guided by commercial reasons: "And this whole triumphant history of culture can be understood as a progressive revelation of the inadequacy of culture itself, as a march toward culture's self-abolition" (Debord, 2002: 48).

Culture is a metareference to the meaning of human existence on the planet that needs to be protected from destruction. Transmedial research imposes itself wherever 'story-transmitted metafiction' is possible, but also where there is no story at its core - in instrumental music, dance, sculpture, architecture, photography 'discourse-transmitted metafiction' can be studied.

How important the context, or the narrative is in a discourse, can be clearly seen in a striking example from media history: young actor Orson Welles directed and performed the radio drama "War of the Worlds" about a Martians' invasion of Earth on the eve of Halloween on October 30, 1938. Although the program was announced as "Mercury Theater on the Air" on CBS, many listeners succumbed to panic because they believed it was a live broadcast. Despite the drama being a radio adaptation of Herbert George Wells' famous 1898 novel "War of the Worlds", the literary work could never have caused such disturbance, but broadcasting over the radio seemed as an informative program - a live transmission of real events. Since then, the United States has banned using term "interrupting the program for an important notification" for dramatic, artistic purposes. That very syntagm is a metareference for the most important news of sudden, often dramatic events and should not be misused.

One of the most prominent features of contemporary post-postmodern culture, especially since the advent of the Internet and the World Wide Web (1995), is the huge increase in meta-phenomena in all fields, from traditional art types and genres to net. art forms. Metareferentiality has spread so much "to various branches of the popular media led to the coinage of the term 'metapop"' (Dunne, 1992, Noth, 2008: 27). The metapop is rapidly transferring children's literature into the world of animated and feature films, video games, comics, television series, but also vice versa, expanding to the literature as a whole, from popular to high-art genres. The metaization of the entire culture is referred to as the "metareferential turn". 


\section{The metareferential turn}

For a long time, media research has looked up to the tradition of literary studies, from which the terms such as 'narrativity', 'intertextuality' or 'miseen abyme' have been borrowed. The concept of text has been expanded from the narrower understanding of what is written or printed to the broader notion that everything can be text: photography, picture, movie frame, sculpture, musical composition, financial statement, binary coded message. Because of the confusion this brings to theoretical considerations and practical research, the concept of intermediality was introduced, which refers to any transgression of boundaries between media. The adaptation of a literary work is not the same if a film or television drama is made, with each medium having its own specific internal composition, so it is not a mere adaptation. But even adaptation is not simply a transfer of narratives from one medium to another, from one to another artistic species. Adaptation is always a kind of creative destruction: "Setting up one piece offers great creative possibilities, which become even greater as the adaptation moves from one medium to another. Critics who complain that a movie or a play is just a bad 'copy' of the original forget that adaptation through the media is not any kind of processing, but a greatest degree of freedom possible. In fact, it often happens that trying to make a strict copy of something ends up being a failure" (Abbott, 2008: 185).

Intermediality encompasses the intra and extra relations of media as means of communication and fusion of semiotic systems. By the term media, we imply all kinds of traditional and new media, from literature and print, painting, photography, film, comics, radio, television to digital media. However, while this term is more appropriate to the modern age of media culture than older terms taken from the literature, it is still not comprehensive: it does not register some extramedial specificities.

Therefore, the term transmediality developed by Irina O. Rajewski (2002: 206) and Werner Wolf (2002a) is increasingly used in the 21st century, and the main reason is that it transcends intermedial transpositions and captures the general phenomena that occur simultaneously in many media. It could be said that transmediality manages to "capture" and transmit the "spirit of time", but also to make specificities from one medium a systemic phenomenon: framing structures from comics and film, descriptivity, narrativity. All of these are rapidly becoming transmedial concepts, which further develop interdisciplinarily so that contemporary studies are almost unimaginable without the terms "transmediality" and "cognitive narratology", no matter on what media - artistic or primarily informative - we focus in a research.

Metareference as a key term of transmediality is the most appropriate research term, even for non-verbal content. In a strictly semiotic sense, it signifies the relation of verbal cues to a world beyond linguistics. Metareferences in the media can be considered a realization of a higher level of mimesis of contemporary culture, because the media themselves today have gained the highest importance in the history of civilization, not only representing reality, but also constructing it and critically 
reflecting their own work. The hypermediation of culture may be understood as a decadent engagement of the media with themselves, but the positive function of metareferences is the increase in media literacy and the collective memory of society, which encourages the development of a critically oriented public.

A significant increase in media metaization in the Western culture is a phenomenon that can be termed a 'metareferential turn', similar to the other 'turns' started after World War II, most notably the linguistic turn of 1950. Researcher Martin Butler noted the rapid increase in metareferences in popular music and thought that confirmation of this phenomenon in other areas would indicate that a 'metareferential turn' had indeed taken place.

Media theorist Marie-Laura Ryan incorporates technical, semiotic and cultural aspects into her analysis of transmediality, considering them constitutive of the concept of metareference (Ryan, 2005: 288-290). However, there are no definitive answers to the question of how metaization has flooded contemporary culture and made mediatization a process in which the media today are equally engaged in the exploration of real events and media products, breaking the boundaries between these spheres. The metaleptic breaking of barriers confirmed the idea of author Vladimir Nabokov that the word "reality" should always be written between quotation marks because dream, awakeness and media creation are just different aspects of what we consider to be reality (Genette, 2004: 93).

The first decades of the 21st century saw an enormous increase in metareferentiality in the media and the arts on a global level, and this change in presence also increased their quality. The technological development of the media and their mutual influence through multimediality and transmediality, as well as the readiness of society and the new cultural context for self-reflection, have certainly contributed to this. From an anthropological point of view, this may be a confirmation of the thesis of a "culture of narcissism", about which wrote American historian and social critic Christopher Lasch (1979).

Irish writer Oscar Wilde's witty grasp that "life imitates art far more than art imitates life" (2015) has fully come true. Reality shows - metareferences to real life allow ready individuals to expose themselves to voyeuristic views due to scopophilia urge (Mulvey,1985: 801-816) to briefly reach Warhol's "15 minutes of glory" and gain celetoid status, a surrogate for the status of a celebrity (Vukadinović, 2013: 170).

Many media theorists and researchers are wondering if all this is enough to declare a 'metareferential turn', as has happened in other fields, especially since the 1980s. Most believe that a change in research perspective is a sufficient reason for that, while others insist also on a change of the subject being discussed. Werner Wolf recalls that he came across the terms 'intermedial turn' and 'metafictional turn' back in 1992, and in 2006 a 'reflexive turn'. He does not miss the opportunity to emphasize that Kaube (2006: 19) "facing such an inflation of turns, from an ironic perspective, produced the metareferential term 'turnological turn"' (Wolf, 2011:5).

The emergence of new terms should signify the naming of entirely new phenomena, significant changes in practice. Still, some cautious researchers are 
wondering: has there really been a metareferential turn? They believe there have always been metaphenomena in art and the media. Metareferences occur in ancient drama, in pseudo-parodies of Homer. The most famous work that abounds in such metareferences is Aristophanes' "Frogs" (1978), first performed in 405 BC. This comedy has two levels of meaning: at the forefront is the war between Athens and Sparta and the presentation of the idea that salvation is in return to the ideals of the past, from the times of the victories at Marathon and Salamis. Aristophanes portrays this metareferentially, introducing Aeschylus' tragic heroes, who say that the Athenians should have adhered to the principles of moderation and justice, as they would have prevented entry into an endless warfare. The second level of the comedy is a literary critique in our contemporary sense: Aeschylus and Euripides are characters who discuss the aims of poetry and the tragedians within comedy give the play a new meta-dimension. In addition, the title is satirical because it alludes to outsmarting of the sophists, demagogic croaking of the aristocracy, babbling leading to war and ruin, and the frogs are a symbol of such an approach to democracy.

Therefore, the increase in metareferentiality is perhaps just an illusion fueled by the enormous expansion of media production, first by the advent of electronic mass media and then even more by the digitalization and entry into the interactive era of computers and the Internet. Indeed, metaization is nothing new and hence Dan Sperber's anthropological characterization of man as what one may term a 'metareferential animal' (2000a: 6f). Some media theorists point out that the heightened sensitivity to meta-phenomena makes us more aware of their presence: perhaps we even cognitively produce it, because we have come up with the term and are now seeing it everywhere.

Even if it were indeed so, if metareferences have appeared in a much larger number than in the time of ancient Athens, this would not yet be sufficient reason to conclude that a 'metareferential turn' has occurred. Werner Wolf convinced that metaization has increased in a disproportionate and therefore significant quantity and moreover has often reached a new quality in contemporary arts and media: "According to my hypothesis, the metareferential turn is thus not merely the effect of a shift in scholarly perspective but like, for example, the 'visual turn' belongs to the class of 'turns' which denote a change in the objects under discussion as well as in scholarly perspective" (2011: 7).

To conclude this dilemma, not only has our approach changed, but everything we observe and study has changed. Lyrical poetry has always tended to be metareferential, but the most prominent literary genre in our culture - the novel has shown a remarkable propensity for metaization since the age of modernism of the 20th century. This is even more noticeable in the visual arts, not only in abstract painting, but even more so in artists inclined to experiment: Marcel Duchamp's readymade Fountain (1917) is an obvious example of how a usable object - a urinal, is transformed into an artistic one. And once that happens, any ordinary thing can become a metareferential artifact, like a bicycle which is used to movearound a city, but a bicycle is also a decoration on the wall of an apartment as a modern sculpture. 
Postmodernism is the meta-peak of metareference, and since the 1960s, metaization has evolved rapidly in the media, from film to television, for our culture to become a meta-culture in today's digital world: „In this 'meta-culture', scholarly discourse is increasingly and openly concerned not with 'reality out there' but with its own perspectives on reality and even with the accelerated change ('turn') of such perspectives. Western culture seems indeed to have 'gone meta" (Wolf, 2011: 15).

Lastly, the use of the prefix 'meta' itself indicates that the world we live in has changed dramatically: only the terms 'metaphysik' and 'metalogik' are more than two centuries old, followed by an avalanche of terms in the aftermath of World War II, such as 'metacommunication' and 'metalinguistics', 'metatheatre,'metafiction','metarepresentation', followed by an avalanche of terms such as 'metapoetry', 'metapainting', 'metafilm, 'metacomic' et cetera.

Terminology is just one indicator of the 'metareferential turn', the application of metareferences in research is another, and the third is an ontological metalepsis that re-examines the boundaries between art, media and reality. This is a qualitative leap, because the thing that philosophers of earlier centuries have discussed is now portrayed by contemporary media as the possibility of existence of more realities, which makes the reality itself just one of the possible 'story worlds' for each of us. The reality has become virtual, it's a world of "copies without originals", a simulacrum filled with simulations: "Disneyland exists in order to hide that it is the "real" country, all of "real" America that is Disneyland (a bit like prisons are there to hide that it is the social in its entirety, in its banal omnipresence, that is carceral). Disneyland is presented as imaginary in order to make us believe that the rest is real, whereas all of Los Angeles and the America that surrounds it are no longer real, but belong to the hyperreal order and to the order of simulation. It is no longer a question of a false representation of reality (ideology) but of concealing the fact that the real is no longer real, and thus of saving the reality principle." (Baudrillard, 1991: 16).

The grandiose simulacrum has spread to the entire human world, and many postmodern works are metareferences to the ideas and views of the French cultural theorist. Among the most famous is the movie "The Matrix" (1999) in which the main character in one scene holds the book "Simulacrums and Simulation" opened at the beginning of the chapter "On nihilism". This shows what formed the basis for this film, which hinted at the emergence of terror as a spectacle, on which Jean Baudrillard published the book "The Spirit of Terror" (2002).

\section{Mediatization of reality}

The 'metareferential turn' is a qualitative leap and deserves attention from a transmedial and transgeneric perspective in the study of contemporary art and media. The possibility of applying new concepts and tools in interdisciplinary analysis is "conceptual leap and leads to the devising of heuristically valuable categories of analysis" (Bachmann-Medick, 2006/2009: 26). 
It is important to emphasize that the media themselves have contributed to a metareferential turn, as its transmedial nature could not even be manifested outside of them. The centuries-old existence of metareferences in art, more in the comic genres than in the drama and novels, gained momentum and developed rapidly only with the advent of electronic media, for digitalization to integrate entire reality into the process of metaization. Today, these boundaries are permeable and the phenomenon that the media are an inseparable part of reality is termed by many theorists as the 'mediatization of reality'. Unlike Baudrillard's' simulacrum ', this does not mean that reality has disappeared, as in Borges' story $(1935 ; 2015)$ of an empire in which the ruler wants to make a perfect map of the state, by eventually covering the entire empire, the empire disappears and is replaced by a copy: here, reality has retained its realistic frames but is complemented by transmedial crossings and artifacts that enrich it immensely. The 'original' is preserved, but at the same time its virtual variants are present, the reality is mediatized and multidimensional, transcending limited categories of space and time.

The logical question that is often asked is 'why did this happen', or what is the meaning of the transmedial referential turn and the mediatization of reality? Some media theorists provide evolutionary explanations because they assume that the human species is capable of, in fact, extremely talented for metaization and that it constantly perceives and cognitively processes connections (Sperber, 2000). Lenk speaks of man as 'the metarepresenting creature' (Wolf, 2011:26).

Cultural history records that this human capacity is constantly evolving and expanding, and this undoubtedly points to an evolutionary tendency towards an increasing metareflexion of our species as a strategy of survival. Humans are social beings and are increasingly dependent on culture, unlike animals which are instict-driven. Compared to other primates, humans have a greater ability to develop sophisticated meta-representations. The mind theory points out that man is able to perceive potentially dangerous or useful information, to interpret the thoughts, motivations and goals of other members of his species, and that thinking about the thoughts of others is something that makes him evolutionarily superior to all other beings on Earth.

Starting from language, linguists believe that from the semiotic point of view, the "semiospheres" have a general tendency toward self-reflexivity. The system theory explains the rise of meta-phenomena by the tendency of systems to intensify internal differentiation, which increases the need for metareference. In short, the whole evolution of our systems, primarily artistic and media, naturally produces an increasing closeness of people to metareferences. The process of mediatization - the metaization in the media, is affecting the audience that is understanding the media better. "This familiarity through habituation (as well as other factors) in conjunction with an increasing number of people who are 'media-savvy' (Caldwell, 2008: 357), which also includes a heightened awareness of mediality as such, has arguably increased what may be referred to as 'metatolerance"' (Wolf, 2011: 28).

The audience increasingly accepts metaization, understands it better in the media and various arts, but this leads to one paradox: it is more and more difficult 
to think of metareferential innovation in representative media that will provide an aesthetic illusion. The change that has taken place in the media is not a demarcation between acceptance and non-acceptance, it is a change in degree, it has expanded the margins of tolerance within which metaization can coexist with immersion from one narrative to another. Metaization, as a by-product of the development of the media and the metareferential turn, is associated with the postmodernist and narratological deconstruction of binary opposition and the emphasis on the importance of context in relation to the text. It also "blurs the boundaries between a report and a commentary, text and meta-text" (Barthes, 1971: 174).

Despite all the good sides of metaization in the media, including the improvement of media literacy and education of the audience, the critical remarks that it is a symptom of a cultural crisis cannot be overlooked. By this, most critics refer to the famous text by Jean-François Lyotard "La Condition Postmodern: Rapport sur le savoir" (1979), written at the request of the Quebec government. His basic point is that the notion of unity is no longer credible because of the loss of "trust in metanarratives" that have given legitimacy to the traditional and modern societies. The ultimate outcome of these meta-narratives was totalitarianism, and Lyotard believes that postmodern partialization is welcome in a world where diversity must be respected. Partial language games have replaced "big stories" because it is impossible to produce universal knowledge: "The postmodern state is a state of multiplicity, partial stories and truths that are in a competitive relationship" (Lyotard, 2008: 453).

The fear of ideological abuse and totalitarianism that marked the 20th century in Europe and the world, has in the modern age of the mediatization of reality, led to distrust of hetero-referential representation, that is, the orientation of the media towards external reality. The concept of the art for art's sake has already been recorded in history of art as an escape from reality, but today that is a tendency once again: "The more the work of art seeks to liberate itself from external determinations, the more it becomes subject to self-positing principles of organization" (Eagleton, 1994: 351). The problem arises when the media also accept the metareferential preoccupation with these principles.

The dilemma is not easy to resolve, since the 'metareferential turn' and 'mediatization' are indeed fueled by increased autonomy of contemporary arts and media, which is positive, but perhaps this also signifies a loss of social connections and functions? It might be about the state of "exhaustion" to continue through originality, but in that case, metareflections provide an opportunity to overcome this condition. Metareferences have a 'built-in' potential for playfulness in the arts and media.

\section{Conclusion}

Metareferences, as a transmedial concept that signifies cognitive insights from a higher level of consciousness, metaization as a process of self-reflection in contemporary art, and mediatization as a sign of the democratization of contemporary 
media which give the audience a behind-the-scenes look, testify to the authors' newfound creativity and the users' maturity. The rise in metareference to the highest level in history of culture has been made possible by the media knowledge of the recipients, especially the younger generations."Metareference, notably in the form of critical or positive allusions to the workings of the media and to well-known works and authors, may indeed both exploit and appeal to this increased expertise and provide a particularly gratifying form of pleasure to aficionados" (Wolf, 2011:31).

By paraphrasing the title of Roland Barthes' famous book (1971), we note that the "metareferential turn" has provided additional "pleasure in the text" of art and media, that is, meta-satisfaction to connect reality and virtual artifacts in a metaleptogenic universe in which the audience mentally complicits in the creative process. This transformation of art and media enthusiasts into qualified 'prosumers' is a significant step in media education that goes far beyond the basics of media literacy. The reader, the listener, the viewer thus becomes a potential producer, not just a consumer of media content, involved in the development of a product or a service. Technological advances have made a significant contribution to this, but hybrid forms of heteroreferential and meta-referential content could only emerge through the development of an innate ability to metasciously grasp one's own being, the real world, and the multitude of its virtual varieties.

Aristotle's view that "poetry is more a philosophical and serious matter than historiography, because poetry shows more what is general and historiography what is individual" and, therefore, that "is not the poet's task to expose what really happened, but what could have happened, and what is possible under the laws of probability or necessity" (Aristotle, 2008: 71-72), has also been confirmed in our time of the 'metareferential turn' to the essence of being and things. The inscription from the entrance to the temple at Delphi "Know Thyself" is an ancient message meaning that the world cannot be known without self-comprehension. The era of electronic, and now digital media, implies that man must also master understanding of his media extensions.

Metaization is a filter that leaks the best of popular genres into high art, like a 'percolator', it gives them prestige and intellectual status. It can therefore be considered a marketing strategy; but without the aesthetic quality that elevates the status of an artifact and the maturity of popular art and media, the audience remains indifferent. Metareferences are indeed a media self-promotion, but thanks to authors' authenticity and transparency of the creative process, there is no lack of self-criticism. This critical aspect of modern meta-referentiality is a kind of 'inoculation' of a metavirus transmitted through the media. This counteracts the damage that could be caused by mass reception of media content.

Metareferential explorations of the opposites of reality and fiction serve as a kind of applied epistemology for deconstructing our old concepts of reality, in search of objective truth. Metaization should not turn into 'navel-gazing' because media and art have other tasks to do than think of themselves. "All in all, metareference in the media may even be regarded as realizing a higher-level mimesis of present-day culture, since the media themselves have acquired a hitherto unknown importance in 
it, not least as a means of constructing what we perceive as reality" (Noth, 2008: 55). The quotation marks for the word "reality" are implied, and when we hesitate to write them, that already says a great deal about the world and the state of consciousness of the modern mediatized man tormented by doubts about his own existence.

\section{References}

Abbott, H. P. (2008). The Cambridge Introduction to Narrative, Cambridge University Press. Aristofan. (1978). Žabe (The Frogs). Novi Sad: Matica srpska.

Aristotel. (2008). O pesničkoj umetnosti. Beograd: Dereta.

Bachmann-Medick. (2006/2009). Analysekategorien - Cultural Turns: Neuorientierungen in den Kulturwissenschaften. 3rd ed. Reinbek: Rowohlt.

Bart, R. (1975). Zadovoljstvo u tekstu. Niš: Gradina.

Barthes, R. (1971). Del'oeuvre au texte. Revue d’esthétique. 3: 225-232.

Borhes, H. L. (Borges, Jorge Luis 1935; 2015). A Universal History of Infamy (Opšta istorija beščašća). Beograd: Paideia.

Bodrijar, Ž. (Baudrillard, Jean1981; 1991). Simulakrumi i simulacija. Novi Sad: Svetovi.

Booth, W. C. (1952). The Self-Conscious Narrator in Comic Fiction before Tristram Shandy. PMLA. 67: 163-185.

Butler, M. (2009). Please Play this Song on the Radio: Forms and Functions of Metareference in Popular Music. Wolf, 299- 316.

Caldwell, J. T. (2008). Screen Practice and Conglomeration: How Reflexivity and Conglomeration Fuel Each Other, Robert Koler, ed. Film and Media Studies, Oxford: OUP. 327-364.

Debord, G. (1992). La Société du spectacle, Gallimard.

Debord, G. (2002). Society of the Spectacle. Bureau of Public Secrets.

Eagleton, T. (1994). The Ideology of the Aesthetic. Oxford: Blackwell.

Genette, G. (2004). Metalepse - De la figure a la fiction. Paris: Editions du Seuil.

Hempfer, K.W. (1982). Die potentielle Autoreflexivität des narrative Diskurses und Ariosts Orlando Furioso, Eberhard Lämmert, ed. Erzählforschung: EinSymposion. Germanistische Symposien 4. Stuttgart: Metzler. 130-156.

Kaube, J. (2006), Das Mengengerüst des Geistes, Neue Rundschau 117/2: 9-24.

Kellner, D. (2004). Media Culture (Medijska kultura). Beograd: Clio.

Lasch, C. (1979). The Culture of Narcissism: American Life in an Age of Diminishing Expectations, W. W. Norton \& Company.

Lenk, H. (2004). Bewußtsein als Schemainterpretation. Paderborn: Mentis.

Lyotard, J.F. (1979). La Condition postmoderne: Rapport sur le savoir. Collection 'Critique', Paris: Seuil.

Liotar, Ž. F. (2008). Postmoderno stanje, prema zborniku priređivača: Đorđević, Jelena, Studije kulture, Službeni glasnik, Beograd. 
Malvey, L. (1985). Visual pleasure and narrative film. Oxford University Press.

Marks, K. (1969). Prilog kritici političke ekonomije. Beograd: Kultura.

McLuhan, M. (1964; 1971), Understanding Media: The Extensions of Man, (Poznavanje opštila - čovekovih produžetaka). Beograd: Prosveta.

Nöth, W. (2007). Self-Reference in the Media: The Semiotic Framework, Nöth/Bishara, eds. $3-30$.

Nöth, W., Bishara, N. and Neitzel, B. (2008). Mediale Selbstreferenz: Grundlagen und Fallstudienzu Werbung, Computerspiel und den Comics. Cologne: Halem.

Ryan, M.L. (2005). Media and Narrative. David Herman, Manfred Jahn, Marie-Laure Ryan, eds. The Routledge Encyclopedia of Narrative Theory. London: Routledge. 288-292.

Rajewsky, I. (2002). Intermedialität, Tübingen: Francke. - (2003). Intermediales Erzählen in der italienischen Literatur der Postmoderne: Von den giovaniscrittori der 80er zum pulp der 90er Jahre. Tübingen: Narr.

Sperber, D. (2000). Introduction to a volume entitled Metarepresentations: A Multidisciplinary Perspective (2000a: 6f) prema Woolf (2009: 2)

Sperber, D. (2000). Metarepresentations in an Evolutionary Perspective,Sperber, Dan, ed. Metarepresentations: A Multidisciplinary Perspective. Vancouver Studies in Cognitive Science 10. Oxford: OUP. 117-137.

Vajld, O. (2015). O istoriji i umetnosti. Beograd: Paideia.

Wolf, W., Bantleon, K. and Thoss, J. (2009). Metareference across Media - Theory and Case Studies, Rodopi, Amsterdam - New York.

Wolf, W., Bantleon, K. and Thoss, J. (2011). The Metareferential Turn in Contemporary Arts and Media - Forms, Functions, Attempts at Explanation, Rodopi, Amsterdam - New York.

Wolf, W. (2002a). Intermediality Revisited: Reflections on Word and Music Relations in the Context of a General Typology of Intermediality, Suzanne M. Lodato, Suzanne Aspden, Walter Bernhart, eds. Word and Music Studies: Essays in Honor of Steven Paul Scher and on Cultural Identity and the Musical Stage. Word and Music Studies 4. Amsterdam: Rodopi. 13-34.

Vukadinović, M. (2013). Zvezde supermarket kulture. Beograd: Clio.

\section{METAREFERENTNI ZAOKRET I MEDIJATIZACIJA STVARNOSTI}

Rezime: Kvalitativni skok u samorefleksiji savremene kulture koja preispituje propustljivost granica izmedu realnosti $i$ fiktivnih svetova, ubrzan razvojem digitalnih artmedija $u$ $X X I$ veku, označen je u teoriji kao 'metareferentni zaokret'. To je prvenstveno zaokret od heteroreferencijalne usmerenosti na pokušaje predstavljanja objektivne stvarnosti $i$ njenog razumevanja ka samospoznaji koja je moguća samo sagledavanjem celine: sveta koji nije stvorio čovek i ljudskih artefakta, uključujući medije koji prikazuju i kreiraju novu, medijatizovanu stvarnost. Metareference kao transmedijalni koncept kognitivno 
povezuju narative različitih vrsta 'stvarnosti' aktivirajući proces metaizacije - kretanja od referentnog ili komunikativnog nivoa svesti do višeg samorefleksivnog. Time publika mentalno (sa)učestvuje u kreiranju metaleptogenog univerzuma.

Ključne reči: metareference, metaizacija, transmedijalnost, metareferentni zaokret, medijatizacija 